physiology and pathology. Virchow's ablest pupil, Bizzozero at the age of twenty-seven became professor of general pathology at Turin, where he proved himself an attractive lecturer, lucid both in thought and expression. Among the first to study the histology of experimental tuberculosis and to observe cell inclusions-pioneer work anticipating the conception of phagocytosis-he was an early student of the hæmopoietic function of bone-marrow, and in 1882 named the blood-platelets (first noticed by Donné in 1842 and more fully described by Osler in 1873), recognizing their participation in blood coagulation. His "Manual of Clinical Microscopy" (1885) went through several editions and translations. Forced by choroiditis to abandon microscopic work, Bizzozero enthusiastically plunged into sanitary reform. Tall, delicately built, with fine features, he was a victim of chronic neuralgia, which however failed to ruffle his serenity and to curb his mania for work. He died of pneumonia on April 8, 1901. Among his distinguished disciples, Golgi, Bassini and Foà have found international fame.

\section{Deaths of Czech University Workers during the German Occupation}

Dr. N. Wooster, "Brooklyn", Cherry Hinton Road, Cambridge, was recently in Czechoslovakia, and arranged with Prof. J. Belehrádek, rector of the University Charles IV, to receive a list of the staff of Czech universities who died as a consequence of the German occupation. Some of those mentioned have already been referred to in the obituary columns of Nature; but it is of interest to have the complete list arranged, as Prof. Bělehrádek has done, by universities and facultios.

Caroline University : Faculty of Arts : six deaths. Faculty of Medicine: thirteen deaths, including Prof. Hynek Pelc, professor of social medicine (executed); Dr. Vladimír Bergauer, general biology (gassed with his wife at Mauthausen), and Dr. Vladimír Tủma, histology (beaten to death in the Pankrác Prison). Faculty of Science: Prof. František Záviška, professor of theoretical physics (died on his way from the concentration camp) (see Nature, March 9, p. 292) ; Prof. Václav Dolejšek, professor of physical chemistry (died in Terezín); Prof. Jan Auerhan, professor of statistics (executed); Prof. Františk Ulrich, professor of crystallography (mortally wounded while being arrested); Prof. Jaroslav Storkán, professor of zoology (executed); Dr. Radim Nováček, mineralogy (executed).

Czech Technical Institute in Prague: Prof. Viktor Felber, professor of mechanics (executed); Prof. Jaromír Śámal, professor of zoology (executed); Prof. Leopold Srámek, professor of general electrical technology (executed); Prof. Jindřich Svoboda, professor of spherical astronomy (died as a result of imprisonment); Otakar Runa, assistant lecturer in technical mechanics (executed); Oldřich Mirtes, assistant lecturer in technical mechanics (died in Auschwitz); Karel Kaš́lk, assistant lecturer at the Institute of Hydraulics (executed).

Masaryk University (Brno): Faculty of Law : six deaths. Faculty of Medicine: Prof. Karel Horák, professor of anatomy (executed) ; Prof. Jan Florian, professor of histology and biology (executed) (see Nature, March 2, p. 257) ; Prof. Miroslav Krrivý, professor of neurology and psychiatry (died in prison). Faculty of Science : Prof. Vojtěch Rosický, professor of mineralogy (executed); Prof. František Koláček, professor of geography (executed); Prof.
Antonín Šimek, professor of physical chemistry (executed); Dr. František Schacherl (died in a concentration camp).

Beně̌ Technical Institute (Brno): Adolf Zobač (executed) ; Prof. Josef Sahánek, professor of technical physics (died in a concentration camp); Dr. Vladimír Němec (chemistry); V. Beneš ; Dr. Jaroslav Mrkos, assistant lecturer; Dr. Bohuslav Hrdlička ; Jaroslav Potoček, assistant lecturer ; Prof. Bohumil Kladivo, professor of geodetics (died as a result of persecution); Dr. Bedřich Pospíšil, assistant lecturer (died as a result of persecution).

Veterinary Institute, Brno: Prof. Tomáš Vacek, professor of physiology (executed) ; Prof. Jan Bečka, professor of chemistry (executed).

Agricultural Institute, Brno: František Wenzel ; Blahoslav Cermák, Commissioner for the Scientific Institutes (executed); Prof. August Bayer (died in Mauthausen); Dr. Vladimír Krist, assistant lecturer (died in a concentration camp).

\section{Announcements}

Sir Alwxander Cadogan, permanent representative of Great Britain on the Security Council, has been appointed to represent the Government on the Atomic Energy Commission of the United Nations; Sir James Chadwick has accepted the appointment of scientific adviser and alternate representative of the United Kingdom on the Commission.

SIR HenRy DaLe, recently president of the Royal Society, Prof. James Gray, professor of zoology in the University of Cambridge, and Prof. D. M. S. Watson, Jodrell professor of zoology and comparative anatomy at University College, London, have been elected to the board of trustees of the British Museum.

THE following appointments have been made at the University College of Wales, Aberystwyth. Mr. E. F. Nash, to be professor of agricultural economies and advisory economist; Mr. E. G. Bowen, lecturer in the Department of Geography and Anthropology, to be Gregynog professor of geography and anthropology.

THE following appointments have been made in the University of Sheffield: Dr. T. E. T. Bond, to be lecturer in botany; Mr. J. D. Weston, to be assistant lecturer in mathematics.

A symposium on "Metrology" is being organised by the Royal Society and will be held in the Society's rooms at Burlington House, London, on March 21, commencing at 2.30 p.m. A number of short papers dealing with the principal units and standards used in scientific measurement will be read by the director and members of staff of the National Physical Laboratory.

A Discussion on "Some Aspects of the Chemistry of Macromolecules", arranged by Prof. H. W. Melville, will be held at the Chemical Society, Burlington House, London, on April 4 at 2.30 p.m. Those taking part will include: Mr. C. W. Bunn, Prof. M. G. Evans, Dr. G. Gee, Prof. M. Polanyi and Dr. H. W. Thompson.

THE Board of Trade states that some two hundred German scientific workers and technicians have volunteered to work in Great Britain for a limited period in an advisory capacity. These men will be employed by the Government, which will lend them to trade associations and research organisations. 